\title{
Tingkat Kualitas Tidur Pelajar Selama Pembelajaran Daring
}

\author{
Jessica Priscillia Gunawan $^{1 *}$, Herry Christian Palit ${ }^{2}$, Debora Anne Yang Aysia ${ }^{3}$ \\ 1,2,3Program Studi Teknik Industri, Universitas Kristen Petra, Surabaya, Indonesia \\ ( ${ }^{*}$ C13180111@john.petra.ac.id)
}

\begin{abstract}
Abstrak - Pandemi COVID-19 tengah merebak di penjuru dunia, termasuk juga di Indonesia. Pemerintah terus berupaya untuk meminimalisir penyebaran dari virus ini, salah satunya dengan kebijakan pembelajaran daring untuk pelajar. Kebijakan ini menjadi kebiasaan baru di kalangan pelajar dan menuntut pelajar untuk mampu beradaptasi. Kebiasaan baru pelajar untuk melakukan pembelajaran secara daring merubah kebiasaan tidur dan mempengaruhi kualitas tidur pelajar. Kualitas tidur akan berdampak terhadap performansi pelajar pada bidang akademik. Kualitas tidur yang buruk menyebabkan sulit untuk berkonsentrasi, menjadi lebih emosional, dan menurunkan tingkat produktivitas. Sampel penelitian terdiri atas 200 pelajar siswa Sekolah Menengah Atas dan Mahasiswa Strata 1 yang melakukan pembelajaran daring yang berdomisili di beberapa daerah di Jawa Timur. Pengambilan sampel menggunakan metode purposive sampling. Pengukuran kualitas tidur menggunakan kuesioner Pittsburgh Sleep Quality Index (PSQI) dalam Bahasa Indonesia, dan disebarkan secara daring dalam bentuk Google form. Pengolahan data menggunakan statistik deskriptif dengan tabulasi silang dan statistik non-parametrik dengan uji beda Mann-Whitney Test. Hasil penelitian menunjukkan 72,5\% responden memiliki kualitas tidur buruk. Penelitian ini juga menunjukkan bahwa kualitas tidur tidak dipengaruhi oleh jenjang pendidikan dan durasi penggunaan gadget, namun dipengaruhi oleh jenis kelamin dan durasi tidur pada malam hari.
\end{abstract}

Kata kunci: COVID-19; kualitas tidur; pembelajaran daring; PSQI

\section{PENDAHULUAN}

Corona virus disease 2019 atau yang dikenal dengan COVID-19 merupakan penyakit menular yang disebabkan oleh virus corona. COVID-19 menyebar dengan sangat cepat dan telah ditetapkan sebagai pandemi global oleh World Health Organization pada tanggal 11 Maret 2020 (Chambonniere, 2021). Sampai dengan saat ini berbagai negara dari penjuru dunia tengah berperang dengan berbagai varian dari virus corona, tak terkecuali juga Negara Indonesia. Pemerintah Indonesia terus berusaha untuk memutus rantai penyebaran dari pandemi ini dengan berbagai upaya, salah satunya dengan penerapan kebijakan pembelajaran daring untuk pelajar yang dilakukan mulai tanggal 15 Maret 2020 sampai dengan saat ini. Hasil survey dari Kementrian Pendidikan dan Kebudayaan menunjukkan bahwa 98\% perguruan tinggi di Indonesia menerapkan pembelajaran daring (Rustandi, 2020). Kebijakan pembelajaran daring tengah menjadi kebiasaan baru di kalangan peserta didik, kebijakan ini membuat peserta didik tidak dapat pergi ke sekolah atau Universitas untuk melakukan pembelajaran tatap muka. Kebiasaan baru ini berdampak terhadap kualitas tidur siswa dan mahasiswa.

Hasil survei dari National Sleep Foundation menunjukkan bahwa individu yang mengaku punya kesulitan tidur ternyata lebih sulit untuk berkonsentrasi, sulit menyelesaikan tugas, dan menjadi lebih emosional (Rafiudin, 2004). Besedovsky (2019) juga memaparkan bahwa kualitas tidur yang buruk akan menyebabkan sistem imunitas tubuh menjadi lemah, memicu tekanan darah tinggi, menjadi lebih mudah mengantuk, dan mudah merasa kelelahan (Alqahtani, 2021). Global Sleep Survey yang dilakukan oleh Philips dalam rangka memperingati World Sleep Day 2021, menunjukkan bahwa pandemi COVID-19 dan kebijakan work from home telah mengubah kebiasaan tidur masyarakat. Diketahui $41 \%$ responden memiliki durasi tidur lebih banyak, namun merasa tidak puas dengan kualitas tidurnya (Pranita, 2021).

Penelitian terdahulu menunjukkan bahwa masyarakat merasa tidak puas dengan kualitas tidurnya selama kebijakan work from home (belajar dan bekerja dari rumah). Padahal pembelajaran daring telah menjadi kebiasaan baru di kalangan pelajar, dan akan tetap diterapkan meskipun pandemi telah berhasil dilewati. Penelitian ini perlu dilakukan, mengingat pembelajaran daring yang telah menjadi kebiasaan baru, serta belum adanya penelitian yang membahas mengenai kualitas tidur pelajar di Jawa Timur selama pembelajaran daring. Penelitian dilakukan pada masa pembelajaran daring, bertujuan untuk mengetahui kualitas tidur pelajar di Jawa Timur selama pembelajaran daring, tanpa melihat perbandingan dengan kualitas tidur pelajar sebelum 
pembelajaran daring. Penelitian ini diharapkan dapat memberikan gambaran mengenai kualitas tidur pelajar di Jawa Timur, pada masa pembelajaran daring.

\section{STUDI LITERATUR}

Coronavirus disease 2019 merupakan virus yang menyebabkan infeksi pada saluran pernapasan manusia (Hector, 2020). World Health Organization (WHO) menyarankan semua orang untuk meminimalkan mobilitas di luar rumah, dan menggunakan masker dengan benar saat berada di tempat umum (Allam, 2020). Penyebaran virus corona dapat diminimalkan dengan berbagai upaya, salah satunya dengan menjaga jarak. Pemerintah memberikan kebijakan pembelajaran daring bagi pelajar, untuk meminimalkan penyebaran dari virus corona di Indonesia. Pembelajaran daring merupakan kombinasi antara teknik pembelajaran konvensional yang dilakukan secara tatap muka dengan pembelajaran dengan menggunakan teknologi informasi yang menggunakan jaringan internet dengan aksesibilitas, konektivitas, dan fleksibilitas (Gusty, 2020). Penelitian dari Browning (2021) menunjukkan bahwa pembelajaran daring membuat pelajar dengan rentang usia 18 sampai dengan 24 tahun menghabiskan lebih dari 8 jam berada di depan layar komputer setiap harinya.

Tidur terdiri atas dua keadaan yang sering dikenal dengan Rapid Eye Movement (REM) dan Non-Rapid Eye Movement (NREM). Tidur REM terjadi saat kondisi tidur yang disertai dengan adanya mimpi, serta tingginya aktivitas mental dan aktivitas fisik. Tidur REM membuat detak jantung, tekanan darah, dan cara bernapas akan sama saat sedang terjaga. Masa tidur REM akan terjadi empat atau lima kali dengan waktu sekitar 20 menit setiap malam. Pada tidur REM otak akan melakukan konsolidasi mengenai informasiinformasi yang telah didapatkan sebelumnya. Sedangkan tidur NREM memiliki empat tingkatan yang sering disebut dengan tingkatan ringan (1 dan 2) dan tingkatan dalam (3 dan 4) (Rafiudin, 2004).

Penelitian menunjukkan bahwa tidur yang baik merupakan tidur yang mengalami perpaduan antara tidur Rapid Eye Movement dan tidur Non-Rapid Eye Movement. Tidur yang cukup dan tidak terganggu oleh faktor internal akan membuat tubuh lebih cepat untuk mengalami pemulihan stamina. Prasadja (2009) mengatakan bahwa tidur memberi kesempatan tubuh untuk secara otomatis memperbaiki sel-sel tubuh yang rusak, sehingga stabilitas kesehatan dan kebugaran tubuh akan tetap terjaga. Kualitas tidur yang baik dapat meningkatkan selsel saraf otak, yang berdampak terhadap perilaku belajar dan meningat. National Sleep Foundation memberikan rekomendasi durasi tidur berdasarkan pada kelompok usia. Dewasa muda dengan rentang usia 18 sampai dengan 25 tahun direkomendasikan untuk memiliki durasi tidur 7 sampai dengan 9 jam setiap harinya (Rahman, 2021).

Rafiudin (2004) mengatakan bahwa kurang tidur akan memberikan efek yang dramatis pada otak, saat orang mengantuk maka otak akan bekerja dengan lebih keras dan membuat otak menjadi semakin lemah. Alqahtani (2021) memaparkan bahwa kualitas tidur yang baik dipengaruhi oleh beberapa faktor, seperti durasi tidur, frekuensi terbangun saat tidur pada malam hari, durasi terjaga saat sebelum tidur, dan kepuasan keseluruhan terhadap pengalaman tidur. Gangguan tidur merupakan suatu kondisi yang berpengaruh terhadap kemampuan untuk tidur dan berdampak terhadap kuantitas dan kualitas tidur. Tidur yang kurang akan menyebabkan gelisah, kesulitan konsentrasi, menjadi lebih mudah emosi, dan penurunan produktivitas. Gangguan tidur disebabkan oleh berbagai faktor, seperti stres dan kecemasan, gaya hidup, faktor fisik, lingkungan, dan pengobatan. Kualitas tidur yang buruk akan berdampak terhadap gangguan kesehatan dan menyebabkan berbagai macam penyakit, seperti depresi, kecemasan, insomnia, gagal jantung, cedera, dan mengurangi fungsi kognitif. Pengkuran kualitas tidur dilakukan dengan menggunakan instrumen Pittsburgh Sleep Quality Index (PSQI).

Pittsburgh Sleep Quality Index (PSQI) terdiri dari 19 pertanyaan, yang terbagi atas tujuh komponen. Komponen pada Pittsburgh Sleep Quality Index (PSQI) adalah kualitas tidur, latensi tidur, durasi tidur, kebiasaan efisiensi tidur, gangguan tidur, penggunaan obat tidur, dan disfungsi pada siang hari. Setiap komponen memiliki skor 0 sampai dengan 3 sesuai dengan instruksi yang diberikan. Skor dari masing-masing komponen selanjutnya akan dijumlahkan menjadi skor global PSQI dengan rentang 0 sampai dengan 21. Responden dengan skor global PSQI kurang dari 5 dapat dikatakan memiliki kualitas tidur baik, sedangkan responden dengan skor global PSQI lebih dari atau sama dengan lima dikatakan memiliki kualitas tidur buruk. Alqahtani (2021) memaparkan semakin tinggi total skor global PSQI, menunjukkan kualitas tidur individu semakin buruk. 


\section{METODOLOGI}

Penelitian diawali dengan identifikasi masalah untuk menentukan tujuan penelitian. Diperlukan juga studi literatur untuk mendapatkan teori pendukung yang dapat digunakan sebagai acuan dalam melakukan rangkaian tahap penelitian. Selanjutnya dilakukan pembuatan kuesioner untuk mengetahui kualitas tidur responden.

Desain kuesioner ini terbagi atas 6 bagian, yang terdiri dari kriteria responden, profil responden, durasi penggunaan gadget, keluhan gangguan tidur, dan kualitas tidur. Kriteria responden memuat pertanyaan untuk mengetahui apakah responden merupakan pelajar yang berdomisili di Jawa Timur dan sedang melakukan pembelajaran daring. Responden yang tidak memenuhi kriteria tidak diberikan pertanyaan lanjutan, sedangkan responden yang memenuhi kriteria akan diberikan pertanyaan lanjutan seputar profil responden. Bagian profil responden akan memuat pertanyaan seputar jenis kelamin, domisili, jenjang pendidikan yang ditempuh saat ini, asal Sekolah / Universitas, durasi responden melakukan pembelajaran daring, serta jumlah anggota keluarga di rumah yang melakukan work from home (belajar / bekerja dari rumah) bersamaan saat responden melakukan pembelajaran daring.

Bagian durasi penggunaan gadget memuat pertanyaan untuk mengetahui rata-rata waktu yang dihabiskan untuk penggunaan gadget setiap hari. Bagian keluhan gangguan tidur responden bertujuan untuk mengetahui apakah responden memiliki gangguan kesehatan yang mungkin mempengaruhi kualitas tidurnya. Bagian kualitas tidur memuat 19 pertanyaan dari instrumen Pittsburgh Sleep Quality Index (PSQI) yang telah diterjemahkan menjadi Bahasa Indonesia, seperti jam tidur pada malam hari, waktu yang dibutuhkan untuk dapat tertidur setiap malam, jam bangun pada pagi hari, rata-rata jam tidur pada malam hari, frekuensi mengalami gangguan tidur, frekuensi konsumsi obat untuk membantu agar dapat tertidur, kemampuan konsentrasi, dan kualitas tidur secara keseluruhan.

Responden pada penelitian ini terdiri atas siswa Sekolah Menengah Atas dan Mahasiswa Strata 1 yang melakukan pembelajaran daring dan berdomisili di beberapa daerah di Jawa Timur, diantaranya: Kabupaten Banyuwangi, Kabupaten Bondowoso, Kabupaten Jember, Kabupaten Lumajang, Kabupaten Sidoarjo, Kabupaten Situbondo, Kota Malang, dan Kota Surabaya. Kuesioner dituangkan dalam bentuk google form dan disebarkan secara daring melalui media sosial. Sampel penelitian ditentukan dengan menggunakan teknik non probability sampling dengan menggunakan purposive sampling. Purposive sampling merupakan teknik pengambilan sampel dengan memilih responden secara subjektif (Lavrakas, 2019). Jumlah sampel dihitung dengan menggunakan pendekatan rumus Lemeshow dengan total populasi yang tidak diketahui secara pasti.

Perhitungan dilakukan dengan menggunakan pendekatan rumus Lemeshow, dengan tingkat kepercayaan 95\% dan tingkat kesalahan yang dikehendaki sebesar 10\%. Dikarenakan nilai proporsi sebelumnya tidak diketahui, maka nilai P menggunakan nilai estimasi maksimal sebesar 0,5 (Sastroasmoro, 2008). Dari hasil perhitungan, diketahui bahwa jumlah sampel minimal yang dibutuhkan sebanyak 97 responden. Kuesioner akan disebarkan kepada 30 responden pertama untuk dilakukan uji validitas dan reliabilitas terlebih dahulu, untuk memastikan bahwa kuesioner telah valid dan reliabel.

Uji validitas dan reliabilitas dilakukan menggunakan software IBM SPSS Statistics 25. Kuesioner yang telah dinyatakan valid dan reliabel akan disebarkan lebih lanjut, sampai mendapatkan total 200 responden. Kemudian dilakukan pengolahan data dan dianalisis untuk mengetahui kualitas tidur responden. Pengolahan data menggunakan statistik deskriptif dengan tabulasi silang dan uji beda dengan Mann-Whitney Test.

\section{HASIL DAN DISKUSI}

\section{A. Karakteristik Responden}

Penelitian dilakukan terhadap 200 responden, yang merupakan siswa Sekolah Menengah Atas serta mahasiswa Strata 1 yang sedang melakukan pembelajaran daring, dan berdomisili di Jawa Timur. Tabel 1 menunjukkan karakteristik responden pada penelitian ini. Terdapat $42 \%$ responden laki-laki dan 58\% responden perempuan. Berdasarkan jenjang pendidikan, terdapat $50 \%$ responden yang merupakan siswa Sekolah Menengah Atas dan 50\% responden yang merupakan mahasiswa Strata 1 . Responden berdomisili di berbagai daerah di Jawa Timur, yang terbagi atas 33\% responden dari Kota Surabaya, 25\% responden dari Kabupaten Jember, 10\% responden dari kabupaten Banyuwangi, dan 32\% responden lainnya berasal dari Kota Malang, Kabupaten Bondowoso, Kabupaten Lumajang, Kabupaten Sidoarjo, dan Kabupaten Situbondo. 
Mayoritas responden sebesar 98,5\% menggunakan gadget lebih dari 4 jam setiap harinya, hanya 1,5\% yang menggunakan gadget kurang dari 4 jam setiap harinya.

Tabel 2 menunjukkan rata-rata durasi tidur responden pada malam hari. Diketahui bahwa 7\% responden memiliki durasi tidur kurang dari 4 jam setiap harinya, $62 \%$ responden memiliki durasi tidur 4 sampai dengan 6 jam setiap harinya. Sedangkan 31\% lainnya memiliki durasi tidur lebih dari 7 jam setiap harinya. Dari tabel 2 dapat diketahui bahwa mayoritas responden sebesar 69\% memiliki durasi tidur kurang dari 7 jam setiap harinya, sedangkan durasi tidur untuk usia dewasa muda (18 sampai dengan 25 tahun) yang direkomendasikan oleh National Sleep Foundation adalah 7 sampai dengan 9 jam setiap harinya. Kondisi ini menunjukkan bahwa mayoritas responden memiliki durasi tidur kurang. Kurang tidur akan berdampak terhadap kesehatan fisik dan mental, serta dapat mempengaruhi performansi pelajar dalam melakukan pembelajaran daring.

Tabel 3 menunjukkan kualitas tidur responden pada masa pembelajaran daring. Didapatkan bahwa 27,5\% responden memiliki kualitas tidur baik, sedangkan 72,5\% lainnya memiliki kualitas tidur buruk. Tabel 4 menunjukkan tabulasi silang antara kualitas tidur dengan jenis kelamin. Didapati 53 dari 84 responden lakilaki (63,09\%) dan 92 dari 118 responden perempuan (77,96\%) memiliki kualitas tidur yang buruk. Selanjutnya dilakukan uji beda dengan menggunakan Mann-Whitney Test, didapati nilai Asymp.Sig (2-tailed) lebih kecil dari taraf alpha $(0,05)$, sehingga dapat diketahui bahwa kualitas tidur dipengaruhi oleh jenis kelamin.

Tabel 1

Karakteristik Responden

\begin{tabular}{cccc}
\hline Variabel & Kategori & Frekuensi (n) & Presentase (\%) \\
\hline Jenis & Laki-laki & 84 & $42 \%$ \\
Kelamin & Perempuan & 116 & $58 \%$ \\
\hline Jenjang & Siswa SMA & 100 & $50 \%$ \\
Pendidikan & Mahasiswa Strata 1 & 100 & $50 \%$ \\
\hline & Kota Surabaya & 66 & $33 \%$ \\
& Kabupaten Jember & 50 & $25 \%$ \\
& Kabupaten Banyuwangi & 19 & $10 \%$ \\
Domisili & Kota Malang & 18 & $9 \%$ \\
& Kabupaten Bondowoso & 16 & $8 \%$ \\
& Kabupaten Lumajang & 13 & $7 \%$ \\
& Kabupaten Sidoarjo & 12 & $6 \%$ \\
& Kabupaten Situbondo & 6 & $3 \%$ \\
\hline \multirow{3}{*}{ Durasi } & 1-4 jam & 3 & $1,5 \%$ \\
Penggunaan & 5-8 jam & 65 & $32,5 \%$ \\
Gadget / hari & 9-12 jam & 81 & $40,5 \%$ \\
& 13-16 jam & 41 & $20,5 \%$ \\
& $>16$ jam & 10 & $5 \%$ \\
\hline
\end{tabular}

Tabel 2

Durasi Tidur Responden

\begin{tabular}{cccc}
\hline Variabel & Kategori & Frekuensi (n) & Presentase (\%) \\
\hline \multirow{3}{*}{ Durasi Tidur } & $<4$ jam & 14 & $7 \%$ \\
& $4-6$ jam & 124 & $62 \%$ \\
& $7-9$ jam & 61 & $30,5 \%$ \\
& $10-12$ jam & 1 & $0,5 \%$ \\
\hline \multicolumn{5}{c}{ Total } & 200 & $100 \%$ \\
\hline
\end{tabular}


Tabel 3

Kualitas Tidur Responden

\begin{tabular}{|c|c|c|c|}
\hline Variabel & Kategori & Frekuensi (n) & Presentase $(\%)$ \\
\hline Kualitas Tidur & $\begin{array}{c}\text { Baik } \\
\text { Buruk }\end{array}$ & $\begin{array}{c}55 \\
145\end{array}$ & $\begin{array}{l}27,5 \% \\
72,5 \%\end{array}$ \\
\hline \multicolumn{2}{|c|}{ Total } & 200 & $100 \%$ \\
\hline
\end{tabular}

Tabel 4

Tabulasi Silang Kualitas Tidur dan Jenis Kelamin

\begin{tabular}{|c|c|c|c|c|}
\hline \multirow{2}{*}{ Variabel } & \multicolumn{4}{|c|}{ Kualitas Tidur } \\
\hline & Kategori & Baik & Buruk & Total \\
\hline \multirow{2}{*}{ Jenis Kelamin } & Laki-laki & 31 & 53 & 84 \\
\hline & Perempuan & 24 & 92 & 118 \\
\hline \multicolumn{2}{|c|}{ Total } & 55 & 145 & 200 \\
\hline \multicolumn{5}{|c|}{$\begin{array}{c}\text { Tabel } 5 \\
\text { Tabulasi Silang Kualitas Tidur dan Jenjang Pendidikan }\end{array}$} \\
\hline \multirow{2}{*}{ Variabel } & \multicolumn{4}{|c|}{ Kualitas Tidur } \\
\hline & Kategori & Baik & Buruk & Total \\
\hline \multirow{2}{*}{ Pendidikan } & Siswa SMA & 29 & 71 & 100 \\
\hline & Mahasiswa S1 & 26 & 74 & 100 \\
\hline \multicolumn{2}{|c|}{ Total } & 55 & 145 & 200 \\
\hline
\end{tabular}

Tabel 6

Tabulasi Silang Kualitas Tidur dan Durasi Penggunaan Gadget

\begin{tabular}{ccccc}
\hline \multirow{2}{*}{ Variabel } & \multicolumn{4}{c}{ Kualitas Tidur } \\
\cline { 2 - 5 } & Kategori & Baik & Buruk & Total \\
\hline & & & & \\
Durasi & $1-4$ jam & 1 & 2 & 3 \\
Penggunaan & $5-8$ jam & 22 & 43 & 65 \\
Gadget & $9-12$ jam & 23 & 58 & 81 \\
& $13-16$ jam & 9 & 32 & 41 \\
& $>16$ jam & 0 & 10 & \\
\hline & & & & 200 \\
\hline
\end{tabular}

Tabel 7

Tabulasi Silang Kualitas Tidur dan Durasi Tidur

\begin{tabular}{|c|c|c|c|c|}
\hline \multirow{2}{*}{ Variabel } & \multicolumn{4}{|c|}{ Kualitas Tidur } \\
\hline & Kategori & Baik & Buruk & Total \\
\hline \multirow{2}{*}{ Durasi Tidur } & $<7$ jam & 18 & 96 & 114 \\
\hline & $\geq 7 \mathrm{jam}$ & 37 & 49 & 86 \\
\hline \multicolumn{2}{|c|}{ Total } & 55 & 145 & 200 \\
\hline
\end{tabular}


Tabel 5 menunjukkan tabulasi silang antara kualitas tidur dengan jenjang pendidikan. Diketahui bahwa 71 dari 100 (71\%) responden siswa Sekolah Menengah Atas dan 74 dari 100 (74\%) responden Mahasiswa Strata 1 memiliki kualitas tidur buruk. Selanjutnya dilakukan uji beda dengan menggunakan Mann-Whitney Test, dan diapatkan nilai Asymp.Sig (2-tailed) lebih besar dari taraf alpha $(0,05)$. Sehingga dapat diketahui bahwa kualitas tidur tidak dipengaruhi oleh jenjang pendidikan, baik siswa Sekolah Menengah Atas maupun Mahasiswa Strata 1 memiliki kualitas tidur yang buruk.

Tabel 6 menunjukkan tabulasi silang antara kualitas tidur dengan durasi penggunaan gadget setiap harinya. Diketahui bahwa seluruh responden yang menggunakan gadget lebih dari 16 jam setiap harinya memiliki kualitas tidur yang buruk. Selain itu, 143 dari 197 (72,58\%) pelajar yang menggunakan gadget lebih dari 4 jam setiap harinya juga memiliki kualitas tidur yang buruk. Selanjutnya dilakukan uji beda dengan menggunakan Mann-Whitney Test, dan diapatkan nilai Asymp.Sig (2-tailed) lebih besar dari taraf alpha $(0,05)$. Sehingga dapat diketahui bahwa kualitas tidur tidak dipengaruhi oleh durasi penggunaan gadget.

Tabel 7 merupakan tabulasi silang antara kualitas tidur dengan durasi tidur. Diketahui bahwa 57\% responden memiliki rata-rata durasi tidur kurang dari 7 jam setiap malam. Mayoritas responden $(84,21 \%)$ yang durasi tidurnya kurang dari 7 jam memiliki kualitas tidur yang buruk. Sedangkan responden yang memiliki rata-rata durasi tidur lebih dari 7 jam setiap malam, hanya 56,97\% saja yang memiliki kualitas tidur yang buruk. Selanjutnya dilakukan uji beda dengan menggunakan Mann-Whitney Test yang memiliki nilai Asymp.Sig (2-tailed) lebih kecil dari taraf alpha $(0,05)$, sehingga dapat diketahui bahwa kualitas tidur dipengaruhi oleh durasi tidur pada malam hari. Responden yang memiliki durasi tidur cukup (lebih dari atau sama dengan 7 jam setiap malam) berpeluang lebih besar untuk memiliki kualitas tidur yang baik.

Kualitas tidur juga dipengaruhi oleh beberapa faktor, seperti penggunaan obat-obatan untuk membantu tertidur, masalah yang sedang dihadapi, total durasi tidur pada malam hari, waktu yang dibutuhkan untuk dapat tertidur pada malam hari, dan gangguan tidur yang dialami. Hasil penelitian menunjukkan terdapat 11 responden yang menggunakan obat-obatan lebih dari satu kali dalam satu minggu untuk membantu tertidur, dan seluruh responden yang menggunakan obat-obatan untuk membantu tertidur memiliki kualitas tidur yang buruk. Apabila dilihat dari masalah yang sedang dihadapi, hanya $21 \%$ responden yang tidak memiliki masalah sama sekali, sedangkan 79\% lainnya mengatakan ada masalah yang sedang dihadapi.

Berdasarkan pada hasil kuesioner Pittsburgh Sleep Quality Index diketahui bahwa 79,5\% responden membutuhkan waktu selama 30 menit atau lebih untuk dapat tertidur pada malam hari. Dilihat dari gangguan tidur yang dialami, mayoritas responden terbangun tengah malam atau bangun terlalu pagi (63,5\%), terbangun karena ingin ke toilet $(58,5 \%)$, serta kesulitan tertidur karena merasa kedinginan $(57,5 \%)$ atau kepanasan (56\%). Semakin banyak gangguan tidur yang dialami oleh responden akan menyebabkan kualitas tidur menjadi buruk. Kualitas tidur yang buruk menyebabkan pelajar menjadi lebih mudah mengantuk dan kesulitan untuk berkonsentrasi. Kondisi ini akan menyebabkan penurunan pada produktivitas dan performa pelajar saat melakukan pembelajaran daring.

Kualitas tidur yang buruk pada pelajar mungkin dipengaruhi oleh beberapa faktor, seperti aktivitas fisik, gaya hidup, gangguan kesehatan yang dialami oleh individu, dan academic burnout. Saat tidur REM akan terjadi stimulasi otak, dan terkait dengan kinerja otak dalam konsolidasi memori. Gangguan tidur dan kualitas tidur yang buruk menyebabkan terganggunya proses-proses tersebut, menyebabkan sulit konsentrasi, dan menjadi lebih emosional. Kondisi ini tentunya akan berdampak terhadap tingkat produktivitas dan performa akademik dari pelajar pada kegiatan pembelajaran.

\section{KESIMPULAN}

Kualitas tidur yang buruk dipengaruhi oleh beberapa faktor, seperti durasi tidur pada malam hari dan gangguan tidur yang dialami. Sebagian besar responden mengalami gangguan tidur seperti terbangun tengah malam atau terlalu pagi, terbangun karena ingin ke toilet, dan kesulitan tertidur karena merasa kedinginan atau kepanasan. Hasil penelitian menunjukkan mayoritas responden sebesar 72,5\% memiliki kualitas tidur yang buruk, sedangkan $27,5 \%$ responden lainnya memiliki kualitas tidur yang baik. Hasil uji beda dengan menggunakan Mann-Whitney Test menunjukkan bahwa kualitas tidur tidak dipengaruhi oleh jenjang pendidikan dan durasi penggunaan gadget, namun kualitas tidur dipengaruhi oleh jenis kelamin dan durasi tidur pada malam hari. Pelajar yang memiliki durasi tidur cukup (lebih dari atau sama dengan 7 jam setiap hari) memiliki kualitas tidur yang lebih baik dibandingkan dengan pelajar yang kurang tidur (kurang dari 7 jam setiap hari). 
Mayoritas responden sebesar 98,5\% menggunakan gadget lebih dari 4 jam setiap harinya. Dari hasil penelitian, didapati bahwa 74,5\% pelajar yang menggunakan gadget lebih dari 4 jam setiap harinya memiliki kualitas tidur yang buruk. Penelitian ini diharapkan dapat menjadi referensi dan memberikan gambaran kepada pembaca mengenai kualitas tidur pelajar di Jawa Timur pada masa pembelajaran daring. Peneliti selanjutnya diharapkan dapat meneliti hubungan antara kualitas tidur dengan academic burnout selama pembelajaran daring pelajar di Jawa Timur.

\section{DAFTAR PUSTAKA}

Allam, Z. (2020). Surveying the Covid-19 Pandemic and Its Implications. Elsevier Gezondheidszorg.

Alqahtani, S. S., Banji, D., \& Banji, O. J. (2021). A survey assessing sleep efficiency among Saudis during COVID-19 home confinement using the Pittsburgh sleep quality index: A call for health education. Saudi Pharmaceutical Journal. Published.

Browning, M. H. E. M., Larson, L. R., Sharaievska, I., Rigolon, A., McAnirlin, O., Mullenbach, L., Cloutier, S., Vu, T. M., Thomsen, J., Reigner, N., Metcalf, E. C., D’Antonio, A., Helbich, M., Bratman, G. N., \& Alvarez, H. O. (2021). Psychological impacts from COVID-19 among university students: Risk factors across seven states in the United States. PLOS ONE, 16(1), e0245327.

Chambonniere, C., Lambert, C., Fearnbach, N., Tardieu, M., Fillon, A., Genin, P., Larras, B., Melsens, P., Bois, J., Pereira, B., Tremblay, A., Thivel, D., \& Duclos, M. (2021). Effect of the COVID-19 lockdown on physical activity and sedentary behaviors in French children and adolescents: New results from the ONAPS national survey. European Journal of Integrative Medicine, 43, 101308.

Gusty, S., Nurmiati, N., Muliana, M., Sulaiman, O. K., Ginantra, N. L. W. S. R., Manuhutu, M. A., Sudarso, A., Leuwol, N. V., Apriza, A., Sahabuddin, A. A., Hastuti, P., Setianto, A. Y., Metanfanuan, T., Uktolseja, L. J., Jamaludin, J., Gaspersz, S., Karwanto, K., Bungin, E. R., \& Warella, S. Y. (2020). Belajar Mandiri: Pembelajaran Daring di Tengah Pandemi Covid-19. Yayasan Kita Menulis. https://www.google.co.id/books/edition/Belajar_Mandiri_Pembelajaran_Daring_di_T/HSz7DwAAQBA $\mathrm{J} ? \mathrm{hl}=\mathrm{en} \& \mathrm{gbpv}=0$

Hector E, C. (2020). Covid 19 and Ivermectin Prevention and Treatment Update. Journal of Infectious Diseases \& Travel Medicine, 4(S1).

Lavrakas, P. J., Traugott, M. W., Kennedy, C., Holbrook, A. L., Leeuw, E. D. D., \& West, B. T. (2019). Experimental Methods in Survey Research: Techniques that Combine Random Sampling with Random Assignment (Wiley Series in Survey Methodology) (1st ed.). Wiley. https://www.google.co.id/books/edition/Experimental_Methods_in_Survey_Research/LGKzDwAAQB $\mathrm{AJ} ? \mathrm{hl}=\mathrm{en} \& \mathrm{gbpv}=0$

Pranita, E. Kualitas Tidur 62 Persen Warga Asia Pasifik Terganggu Selama Pandemi. Kompas.com, 18 March 2021, https://www.kompas.com/sains/read/2021/03/18/190200223/kualitas-tidur-62-persen-warga-asiapasifik-terganggu-selama-pandemi. Accessed July 19, 2021.

Prasadja, (2009). Ayo Bangun. $\quad$ PT Mizan $\quad$ Publika. https://www.google.co.id/books/edition/Ayo_Bangun/OKtvxXpVHukC?hl=en\&gbpv=0

Rafiudin, R. (2004). Insomnia \& Gangguan Tidur. Van Duuren Media. https://www.google.co.id/books/edition/Insomnia_Gangguan_Tidur/kxhBtckImNQC?hl=en\&gbpv=0

Rahman, F. A. (2021). Lindungi Dirimu dengan $\bar{A} P D$ (Anti Penyakit Degeneratif). Orbit Indonesia. https://www.google.co.id/books/edition/Lindungi_Dirimu_dengan_APD_Anti_Penyakit/BN4iEAAAQ BAJ?hl=en\&gbpv $=0$

Rustandi, D. Dirjen Dikti: Tri Dharma Perguruan Tinggi Tidak Berhenti Meski Pandemi Covid-19. Dikti.Kemendikbud.go.id, 22 October 2020, https://dikti.kemdikbud.go.id/kabar-dikti/kabar/dirjen-diktitri-dharma-perguruan-tinggi-tidak-berhenti-meski-pandemi-covid-19/. Accessed July 19, 2021

Sastroasmoro, S., \& Ismael, S. Dasar-dasar Metodologi Penelitian Klinis (3th ed.). (2008). Sagung Seto. 